\section{Response to: 'Mycophenolate mofetil: a step forward in the induction treatment of ANCA- associated vasculitis? Comment on the article by Jones et al' by Vandergheynst et al}

We thank the authors for their interest in our publication.

As stated in the commentary, ${ }^{1}$ the MYCophenolate mofetil versus CYClophosphamide (MYCYC) trial was originally published in abstract form in 2013; the data published at that time was preliminary. The primary outcome events for the MYCYC trial, defined as remission with glucocorticoid compliance within 6 months, were adjudicated by blinded adjudicators. The differences in results as published ${ }^{2}$ are due to the addition of glucocorticoid dose data made available after the publication of the 2013 abstract. The additional data resulted in a small change in the numbers of primary outcome events and, ultimately, the statistical inference of non-inferiority. These differences highlight the potential for even small, chance occurrences to alter the outcomes of trials and the need for large trials.

We thank the authors for the comparison with the Rituximab for Antineutrophil cytoplasmic antibodies (ANCA)-associated Vasculitis trial, ${ }^{3}$ which helps contextualise the study with other trials. Mycophenolate has never been compared directly to rituximab treatment for induction therapy in ANCA-associated vasculitis and it is difficult to make fair comparisons of therapies between different trials. We agree with the authors that mycophenolate must be used with caution in those at higher risk of relapse, as stated in the discussion. We also recognise that the use of concomitant therapies including intravenous glucocorticoids and plasma exchange may have facilitated early disease control in both groups. The higher relapses in the mycophenolate group suggest that cyclophosphamide may be preferable for patients at high risk of relapse. The current study does not suggest that mycophenolate should be the preferred choice for all but it does provide additional information on the potential risks and benefits of mycophenolate with glucocorticoids as induction therapy for those with nonlife-threatening disease. This is important as other therapies may be contra-indicated or unavailable in some regions.
Rachel B Jones, ${ }^{1}$ Thomas F Hiemstra, ${ }^{2}$ Michael Walsh $\odot ~,{ }^{3,4}$ David Jayne, ${ }^{5}$ Lorraine Harper $\odot^{6}$

'Department of Renal Medicine, Addenbrooke's Hospital, Cambridge, UK

${ }^{2}$ School of Clinical Medicine, University of Cambridge, Cambridge, UK

${ }^{3}$ Population Health Research Institute, Hamilton, Ontario, Canada

${ }^{4}$ Medicine, McMaster University, Hamilton, Ontario, Canada

${ }^{5}$ Division of Nephrology, Addenbrooke's Hospital, Cambridge, UK

${ }^{6}$ Institute of Clinical Sciences, University of Birmingham, Birmingham, UK

Correspondence to Dr Lorraine Harper, University of Birmingham, Birmingham B15 2TT, UK; l.harper@bham.ac.uk

Handling editor Josef S Smolen

Funding The authors have not declared a specific grant for this research from any funding agency in the public, commercial or not-for-profit sectors.

Competing interests None declared.

Patient consent for publication Not required.

Provenance and peer review Commissioned; internally peer reviewed.

(c) Author(s) (or their employer(s)) 2020. No commercial re-use. See rights and permissions. Published by BMJ.

\section{(A) Check for updates}

To cite Jones RB, Hiemstra TF, Walsh M, et al. Ann Rheum Dis 2020;79:e101.

Received 9 June 2019

Accepted 9 June 2019

Published Online First 19 June 2019

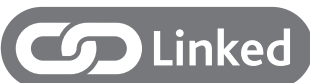

http://dx.doi.org/10.1136/annrheumdis-2019-215647

Ann Rheum Dis 2020;79:e101. doi:10.1136/annrheumdis-2019-215658

ORCID iDs

Michael Walsh http://orcid.org/0000-0001-8292-2014

Lorraine Harper http://orcid.org/0000-0003-1343-9234

\section{REFERENCES}

1 Vandergheynst FA, Lelubre C. Mycophenolate mofetil: a step forward in the induction treatment of ANCA-associated vasculitis? Comment on the article by Jones et al. Ann Rheum Dis 2020;79:e100.

2 Jones RB, Hiemstra TF, Ballarin J, et al. Mycophenolate mofetil versus cyclophosphamide for remission induction in ANCA-associated vasculitis: a randomised, non-inferiority trial. Ann Rheum Dis 2019;78:399-405.

3 Stone JH, Merkel PA, Spiera R, et al. Rituximab versus cyclophosphamide for ANCAassociated vasculitis. N Engl J Med 2010;363:221-32. 